\title{
REPORT ON THE FEASIBILITY
}

OF

\author{
A 15,000 KILOWATT ELECTRIC POWER STATION
}

USING GEOTHERMAL HEAT SOURCES

AT

MAMMOTH AREA, MONO COUNTY, CALIFORNIA

PREPARED FOR

THE MAGMA-NATURAL STEAM POWER PROJECT
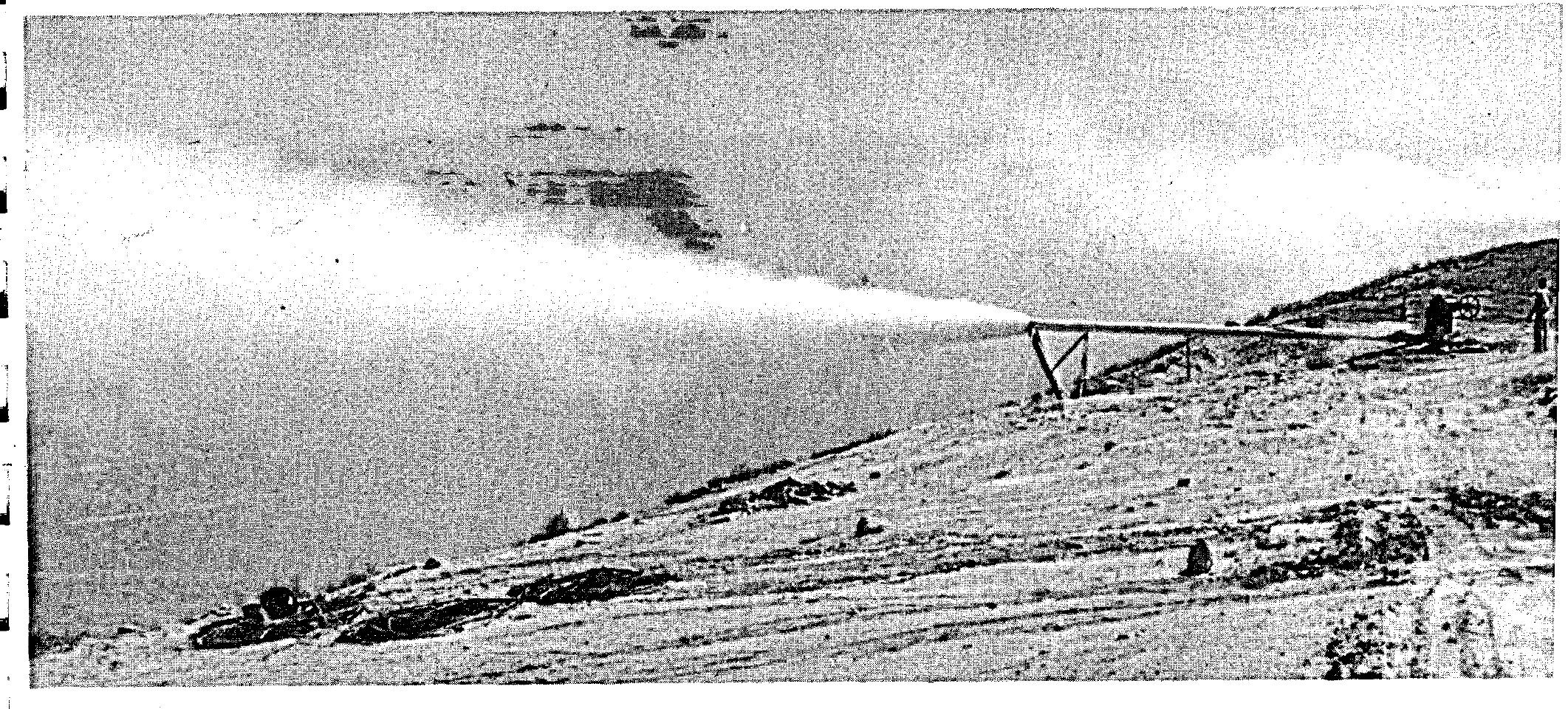

\author{
PREPARED BY \\ ROGERS ENGINEERING CO., INC. \\ 16 BEALE STREET \\ SAN FRANCISCO 5, CALIFORNIA
}




\section{DISCLAIMER}

This report was prepared as an account of work sponsored by an agency of the United States Government. Neither the United States Government nor any agency Thereof, nor any of their employees, makes any warranty, express or implied, or assumes any legal liability or responsibility for the accuracy, completeness, or usefulness of any information, apparatus, product, or process disclosed, or represents that its use would not infringe privately owned rights. Reference herein to any specific commercial product, process, or service by trade name, trademark, manufacturer, or otherwise does not necessarily constitute or imply its endorsement, recommendation, or favoring by the United States Government or any agency thereof. The views and opinions of authors expressed herein do not necessarily state or reflect those of the United States Government or any agency thereof. 


\section{DISCLAIMER}

Portions of this document may be illegible in electronic image products. Images are produced from the best available original document. 
WorM. Middens

$\frac{\mathbb{R}}{12 / 8 / 81}$

O.0. Box 327

Novas Calif.

94948

$707-762-7910$

Nepenthe II

Berth iv 3

Oat forme.

Talked to Bill Middleton re Binary Cycle Geothermal Power Plant study in dob 1771 for Magma Power!

Bill indicated he was the original developer of the patent, not B.C. Melos This was a suprise to me!

Evidently the is going to court on this matter!

I could not give tim a copy of report, as Magma paid us for the study! The study is therefore property of Magma Power Co.

Hi Rogers.

$12 \% 0181$ 
REPORT ON THE FEASIBILITY

OF

A 15,000 KILOWATT ELECTRIC POWER STATION

USING GEOTHERMAL HEAT SOURCES

AT

MAMMOTH AREA, MONO COUNTY, CALIFORNIA

PREPARED FOR

THE MAGMA-NATURAL STEAM POWER PROJECT

COPY NO. 84

\author{
PREPARED BY \\ ROGERS ENGINEERING CO., INC. \\ 16 BEALE STREET \\ SAN FRANCISCO 5, CALIFORNIA
}

JANUARY 1962 


\section{TABLE OF CONTENTS}

SECTION

TITLE

PAGE

1

INTRODUCTION

2

Purpose

Scope

Heat Cycles

SUMMARY OF CONCLUSIONS AND RECOMMENDATIONS

Conclusions

Recommendations

3

DISCUSSION

Flash Steam Cycles

Closed Power Fluid Cycles

Well Production

Effluent Disposal

4

COST ESTIMATES

Construction Costs

11

Operating Costs

Double Flash Steam Cycle

Closed Power Fluid Cycle

12 


\section{INTRODUCTION}

\section{A. Purpose}

This report comprises a study of all factors pertinent to the feasibility and economics of converting into electric power, the geothermal energy issuing from drilled wells. The study applies particularly to wells in the Mammoth area, California, but many of its conclusions may be applied to other locations.

B. Scope

The scope of this report includes:

1. Evaluation of heat cycles for the conversion of the geothermal energy to electric power in a single unit 15,000 kilowatt plant.

2. Selection of the most satisfactory flash-steam cycle and the most satisfactory closed power fluid cycle for more direct comparison.

3. Estimates of plant construction and operating costs for the cycles selected for comparison.

4. Schedules showing estimated start-up and firm operating dates for the cycles selected for comparison.

5. Drawings showing typical plan arrangements and elevations of plants utilizing the cycles selected for comparison.

6. Review of current data on well production and on the available means for effluent disposal.

7.) Conclusions and recommendations.

\section{Heat Cycles}

There are a number of ways by which geothermal energy may be converted to electrical power. These fall into two general classes:

1. Those cycles involving the use of steam flashed at reduced pressures in one or more steps, passing the steam through a suitable turbine and condensing it in a partial vacuum. The cooled water and the condensate are then discharged to a sink or stream. No boiler feed pump is required. Preliminary studies indicate at this time that the double-flash cycle is the most economical of the plant steam cycles for the conditions at Mammoth and is the steam cycle used in this report. 
2. Those cycles in which the heat is transferred to some other power fluid which in turn is passed through a turbine to a surface condenser and returned by means of a boiler feed pump to the heat exchangers and boiler. There are several fluids available for this service such as various refrigerants as well as hydrocarbons of which butane is an example. (Note that throughout this report, the refrigerants commonly known as Freon, Genetron, Payon 12, 22, 114, etc., will be referred to as refrigerant 12, 22, 114, etc.) The critical characteristics of these fluids vary considerably and if this type of cycle were found to offer the most economical plant design a more extensive study of them would be indicated.

There is, however, one characteristic which appears to be more or less common to all the special fluids. The heat available for use in a turbine between the limiting temperatures is relatively small per pound of fluid as. compared to water, resulting in a large flow of fluid for a given output. This large quantity must be returned to the heat exchangers and boiler. The boiler feed pump power can therefore be a large fraction of the gross turbine output.

One of the major turbine and refrigeration equipment manufacturers has made a study of the possibilities of these fluids; and, for the purposes of this feasibility report, their presentation and estimate for the equipment has been accepted using refrigerant 12 . It is felt that the use of other fluids, while they might improve the economics somewhat, would not effect the first decision whether to use the flash steam cycle or the clased power fluid cycle.

The designs shown in this report are, of necessity, based on average considerations. Improvements in performance may be made by incorporating special heat exchanger designs, cooling towers operating with a closer approach to the dew point, triple flash cycles, etc. It is contemplated that complete economic studies of possible efficiency improvements would be carried out for the final design. 
SECTION 2.

\section{SUMMARY OF CONCLUSIONS AND RECOMMENDATIONS}

The following is a summary of the conclusions and recommendations.

A. Conclusions

1. The plant design which will produce electrical energy for the least cost comprises a double flash steam cycle with a dual entry steam turbine together with the necessary auxiliary equipment and housing.

2. Alternate designs utilizing special power fluids in a closed cycle are applicable to this geothermal energy source. However, investigation of the history of these fluids for power generation show:

(a) Progress in the application of special fluids as a power medium is rather limited.

(b) Thermodynamic data in table or chart form are not readily available in the temperature ranges suitable for power generation.

(c) A rather limited number of units is in service, and many of these are located in classified industries.

(d) Maximum size of units in service is about 750 kilowatts.

(e) Access to operating records of existing turbines is rather difficult, if not impossible and, because of the extreme difference in size, could not be considered as truly applicable.

3. For size of unit which is the subject of this report, refrigerant 12 appears to be the most suitable power fluid available. Refrigerant 114 and butane would give a higher theoretical efficiency but the high specific volumes at the lower pressures for the temperatures available, make the physical size of the equipment impractical. The latter refrigerants are not recommended by the equipment manufacturer for this size of unit.

4. While the closed cycle requires less water-steam mixture per net kilowatt hour output than the double flash steam cycle, the greater first cost more than offsets any advantages. 
5. A closed cycle in the size under consideration will require utilization of specially designed equipment for which there is no operating experience on which to predict the reliability of plant performance.

6. Availability of sufficient and continuous geothermal flow appears to be certain, based on existing geological and test data. However, conclusive proof is yet to be established.

7. The most satisfactory means of effluent disposal have as yet not been determined.

B. Recommendations

Based on the foregoing conclusions, it is recommended that:

1. The double-flash cycle with a dual entry steam turbine be selected as the basis for design of an electrical power generating station.

2. A program be initiated at an early date to establish proof of continuous well flow.

3. A program running concurrently with item 2 above be established to determine a satisfactory means of well effluent disposal.

4. On the basis of items 2 and 3 being accomplished to the satisfaction of all concerned, that then a contract be negotiated with a prospective customer to sell him electrical energy based on the costs of a complete electric power generating station making use of the double-flash steam cycle.

5. Following successful negotiations, an electric power generating plant in general accordance with the heat-power cycle using the double-flash system be designed and constructed.

6. Based on research and engineering to date relative to the use of other power fluids, consideration be given to the merits of further study in this field in subsequent development work at this or other sites. 
SECTION 3.

DISCUSSION

A. Flash Steam Cycles

1. Cycles considered were single, double, and triple flash with variations to include superheating of steam before entering the turbine. The cycles using flashed steam are shown on Diagrams 1 through 5, attached.

Superheating is accomplished by first passing the hot water through a. heat exchanger in series with the flash tank and turbine before entering the turbine. The small efficiency gain by superheating does not seem to justify the additional costs involved.

As between the single, double, and triple flash cycles, the double improves the efficiency about $25 \%$ over the single flash and the triple flash is about a $10 \%$ improvement over the double flash. The additional costs of the double flash system over the single flash are well justified. It is questionable, however, with the conditions expected at Mammoth, that the increase in theoretical efficiency utilizing the third flash would justify its increased costs. In addition, the third stage would operate below atmospheric pressure with the possibility of air infiltration, a serious matter with hydrogen sulphide in the steam. The specific volume of the steam at sub-atmospheric pressures means large and expensive ducts. It is probable, therefore, that the three flash system would not be justified, although this cannot finally be determined before establishment of the cost of steam and the rate of fixed charges to be used. In view of the above considerations the two flash cycle has been selected for the purpose of this report.

2. The equipment for conversion of heat energy in the form of steam to electrical power is the steam turbine, which has a well proven and accepted performance record. The basic equipment of a plant incorporating the double-flash cycle comprises the following items: a turbine-generator, barometric condenser, non-condensable gas removal system, two-stage flash tank, cooling tower, circulating water pumps and plant auxiliaries.

The steam turbine is available and similar units are being currently manufactured by several well qualified manufacturers. The service conditions at the Mammoth area would be no more severe than those imposed on process turbines now in service throughout the United States. 
Surface, barometric, and low level jet condensers are types available for power station use. The surface condenser is expensive and unnecessary if the condensate is not to be returned to a boiler. The barometric and jet condensers mix the condensate with the cooling water. Either would be satisfactory. The low level jet condenser requires less head room but needs a pump for removal of condensate and circulating water. The terrain is such at the Mammoth area that it may be possible to attach the barometric condenser directly to the turbine exhaust and eliminate costly and cumbersome exhaust ductwork.

Non-condensable gas removal equipment requires careful study for sizing because of the abnormally high ratio of non-condensables to steam flow as compared to conventional steam-electric power stations having boilers being fired with a fuel such as gas, coal and oil.

The two-stage flash tank for separation of steam and water can be made more economically as a single vessel with a partition to form two chambers than as two separate vessels. The compact design will lend itself well to keeping pipe runs and pressure drops at a minimum.

Cooling towers, circulating water pumps, and auxiliaries are all standard equipment. Mechanical draft towers have been selected in preference to spray or cooling ponds for the purposes of this report but the latter would be reconsidered in a final design.

\section{B. Closed Power Fluid Cycle}

1. Cycles considered vary only as to the power fluid used. Several refrigerants were studied as well as butane and hexane. The flow diagram of the closed power cycle is shown on Diagram 6, attached.

2. The refrigerant most compatible to expected geothermal well temperatures at Mammoth, the present state of special power fluid turbine design, cost of refrigerant inventory and total plant cost is refrigerant 12. This may not be true for conditions at other locations. A study to determine the lowest well temperature applicable to economical development of power, at any particular site, involves the above items and other factors. Among these are the cost of money and the market for power. Temperatures referred to are those of the aquifer or water stratum and are not to be confused with temperatures at the well heads.

The closed power fluid cycle selected to be the most favorable for this study makes use of refrigerant 12 and is the only one for which equipment costs could be obtained. The basic plant equipment comprises the following items: a turbo-generator, surface condensers, condensate booster pump, boiler feed pump, heat exchangers, unfired boiler, unfired superheater, flash tank, cooling tower, circulating water pump, and plant auxiliaries. 
3. The turbine proposed for this cycle is, in contrast to the axial flow type of design currently used as a prime mover, comprised of a radial inflow wheel designed to permit expansion of the power fluid. Actually, in appearance, it is very similar to a centrifugal pump.

Interest was not keen enough at this time for other manufacturers to submit a proposal, but discussions with their engineers revealed that they may possibly favor an axial flow turbine. Discussions also revealed that engineers were less familiar with approaches to establishing optimum conditions in the use of special power fluids as compared to water and steam. This is not to be construed as a reflection on the ability of the many capable engineers and engineering groups now engaged in this work, but emphasizes rather strongly that research and practice in the application of special fluids as a medium of power generation has been and is, rather limited. Standard shell and tube condensers are used in the preliminary design. In the final design of any cycle making use of the special fluids, two half-sized condensers would probably be the maximum number for a single turbine, and more than likely, a single full capacity condenser per turbine would be the most economical selection. The condensers are designed for water flow through the tubes and refrigerant 12 flow on the exterior surfaces in a cross flow pattern.

To return the condensate to the heat exchangers and boiler, a booster pump and boiler feed pump operating in series are necessary. The total power requirements of these two pumps is approximately $3000 \mathrm{hp}$. The boiler feed pump is directly connected to the main generator shaft with a motor drive for the booster pump for starting purposes.

The proposed heat transfer units for transfer of geothermal heat energy to the power fluid comprises four heat exchangers, one boiler, and one superheater, all being of the shell and tube type. Boiling and superheating of the power fluid is done entirely by the flashed steam with condensed steam discharging to the heat exchangers for additional transfer of heat to the power fluid.

The flash tank required for this cycle is to be a single flash type for separation of water and steam. Efficiency requirements of a flash tank to produce dry steam need not be as high as the requirements for a steam turbine, cycle. 
The cooling tower selected is to be of the mechanical draft type with one pump, or possibly two half capacity pumps in parallel, providing the means of circulating the condensing water. Well water is to be used for the circulating water inventory and make-up. Cooling tower maintenance could possibly be more of a problem in this cycle than the steam cycle where condensate only is used in the cooling water system. Again spray or cooling ponds would be considered in the final design.

4. Potential cycle improvements may result with the use of a fluid with more advantageous thermodynamic properties. However, not to be overlooked is the cost of a power fluid and how its pressure and temperature may effect design requirements of the equipment.

\section{Well Production}

Although the availability on a continuous basis of sufficient energy to supply a $15,000 \mathrm{kw}$ electric generating plant has not yet been demonstrated fully, this should be no point for alarm except possibly the disposal of effluent as covered below. Due to the precipitation of calcium in the well casings during flow, well production is reduced and may even cease. However, a suitable maintenance program of routine cleaning of the well bore should insure sufficient energy for continuous production of full plant output. Wells in both Italy and New Zealand are operating very satisfactorily under such a maintenance program. Chemical injection into the wells to hold the calcium in solution is to be tested in wells of similar characteristics in the State of Nevada and may prove to be a more satisfactory and less costly means of maintaining clean well bores.

Present geological and well test data indicate that an ample supply of heat energy is available. The studies have been made on the assumption that the wells will supply this energy at a pressure of at least 50 psia at the flash chamber. This may not necessarily represent the optimum condition, determinable only from flow test data of the individual wells. Conclusive proof of continuity of well production also should be demonstrated, following completion of the flow tests.

D. Effluent Disposal

Discussions were held with the public agencies concerned with the controls and/or regulations affecting water disposal in the area. These agencies desire that discharge into any water source subject to public service does not cause these sources to exceed recommended limitations established by these agencies. The Lahontan Regional Pollution Control Board is quite insistant that geothermal well effluents be regulated and monitored with respect to flow rates and chemical composition if discharged in the nearby area. 
The most apparent means of disposal is into the nearby streams, but chemical composition of well effluents may place limitations on this possibility.

Another means of water disposal that may be practical is re-injection into drilled wells, and perhaps be more attractive economically than other means. Ponding of the water should also be considered. Both of the latter pose a question of percolation that concerns some agencies. Therefore, well effluents should be monitored with respect to flows and chemical composition before a final conclusion is reached on the most satisfactory means of well effluent disposal. Quantity of water to be disposed of after use in the recommended plant will be about $4000 \mathrm{gpm}$. The Board members have indicated their desire to cooperate in determining the best method of water disposal. 
SECTION 4.

\section{COST ESTIMATES}

A. Construction Costs

The estimated capital costs of the two types of plants described previously in this report are as follows:

1. Two-Stage Flash Steam Cycle $\$ 2,100,000.00$ Cost per net KW of capacity $\$ 140.00$

2. Refrigerant 12, Closed Power Fluid Cycle Cost per net KW of capacity

$\$ 2,800,000.00$ $\$ 187.00$

The designs provide for a net output of $15,000 \mathrm{kw}$ during summer weather conditions. In the colder seasons the net output would be slightly greater. The figures include provision for contingencies and engineering, property improvements, interest during construction, etc., but do not include well and collecting piping costs, the step-up transformer, high voltage switching. structures nor working capital.

B. Operating Costs

Annual costs of either plant will approximate the following:
Administration
$\$ 20,000$
Operation \& Maintenance
$\$ 70,000$

The cost of steam and/or water must be added to the above. The items of administration and operation and maintenance are based on the assumption that the plant would be operated as a separate entity. If it were to become a part of a system, these costs could be materially reduced. Property and income taxes, insurance, cost of money, etc., must be established before a kilowatt-hour cost can be determined. 


\section{SECTION 5.}

\section{CONSTRUCTION SCHEDULES}

A. Double Flash Steam Cycle

The schedule for this system is predicated on turbine delivery. The turbine order should be placed 3 months after start of final engineering. Delivery is estimated at 12 months. Installation should take an additional 3 months after delivery.

Start-up is then estimated at 18 months after start of final engineering. Firm power should be available 4 months after start-up.

B. Closed Power Fluid Cycle

The schedule for this system is also predicated on turbine delivery. The turbine order should be placed 5 months after start of final engineering. Delivery is estimated at 18 months. Installation should take an additional 3 months after delivery.

Start-up is then estimated at 26 months after start of final engineering. Firm power should be available 4 months after start-up. 
SECTION 6

DRAWINGS AND DIAGRAMS

A. Drawings attached to this report are as follows:

1. $15 \mathrm{MW}$ Steam Electric Power Station

Dwg. No.

Títle

$1771-62-1-0$

Flow Diagram and Heat Balance

$1771-62-2-0$

General Arrangement Plan

$1771-62-3-0$

General Arrangement Section

$1771-62-4-0$

One Line Electrical Diagram

2. $15 \mathrm{MW}$ Closed Power Fluid Electric Power Station

Dwg. No.

Title

$1771-62-5-0$

$1771-62-6-0$

Flow Diagram and Heat Balance

$1771-62-7-0$

General Arrangement Plan

$1771-62-8-0$

General Arrangement Sections

One Line Electrical Diagram

B. Heat cycle diagrams attached to this report are as follows:

\begin{tabular}{|c|c|}
\hline 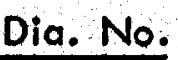 & Title \\
\hline $\begin{array}{l}1 \\
2 \\
3 \\
4 \\
5 \\
6\end{array}$ & $\begin{array}{l}\text { Single Flash } \\
\text { Double Flash } \\
\text { Triple Flash } \\
\text { Single Flash and Superheat } \\
\text { Triple Flash and Superheat } \\
\text { Closed Power Fluid }\end{array}$ \\
\hline
\end{tabular}



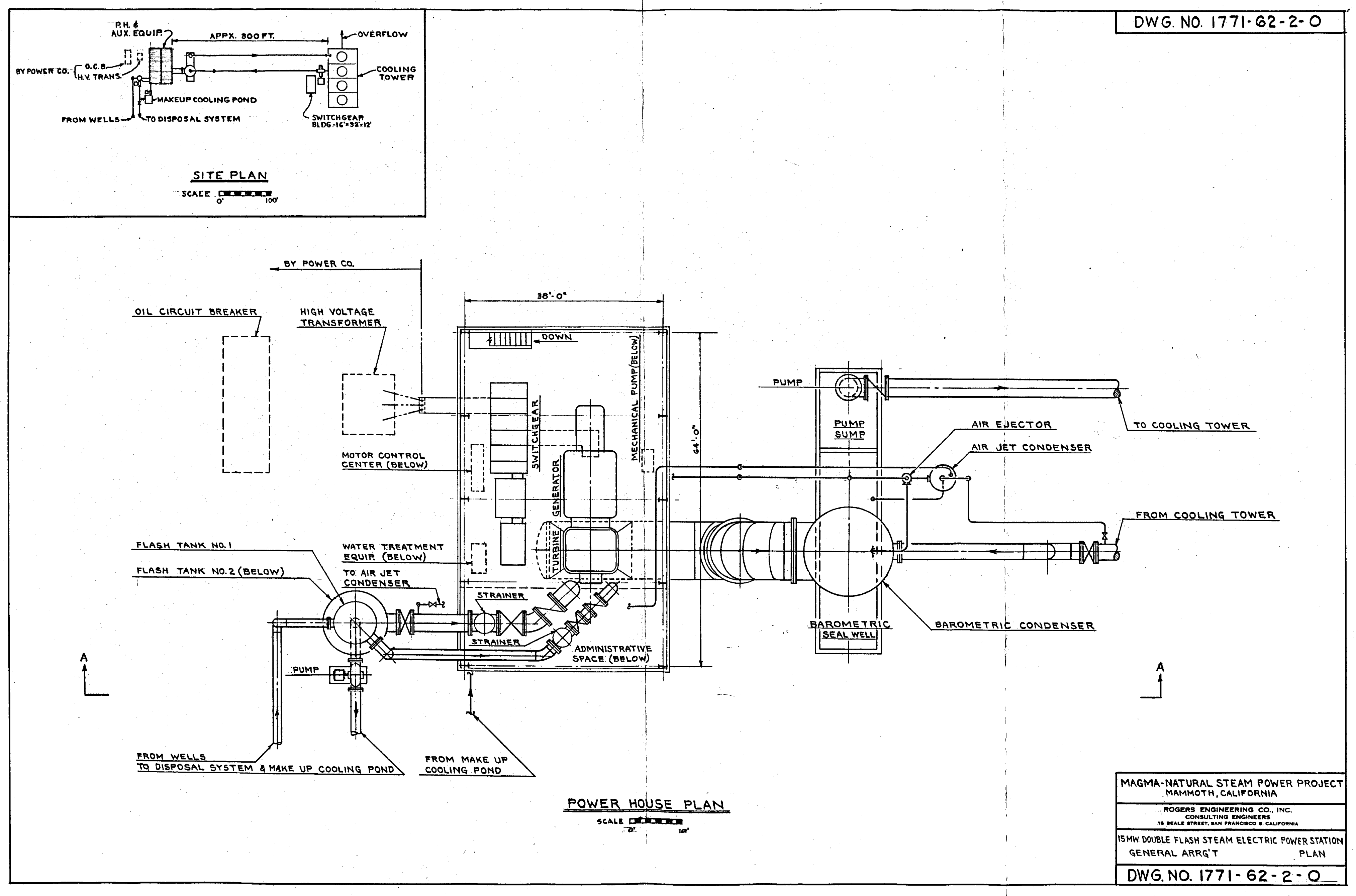


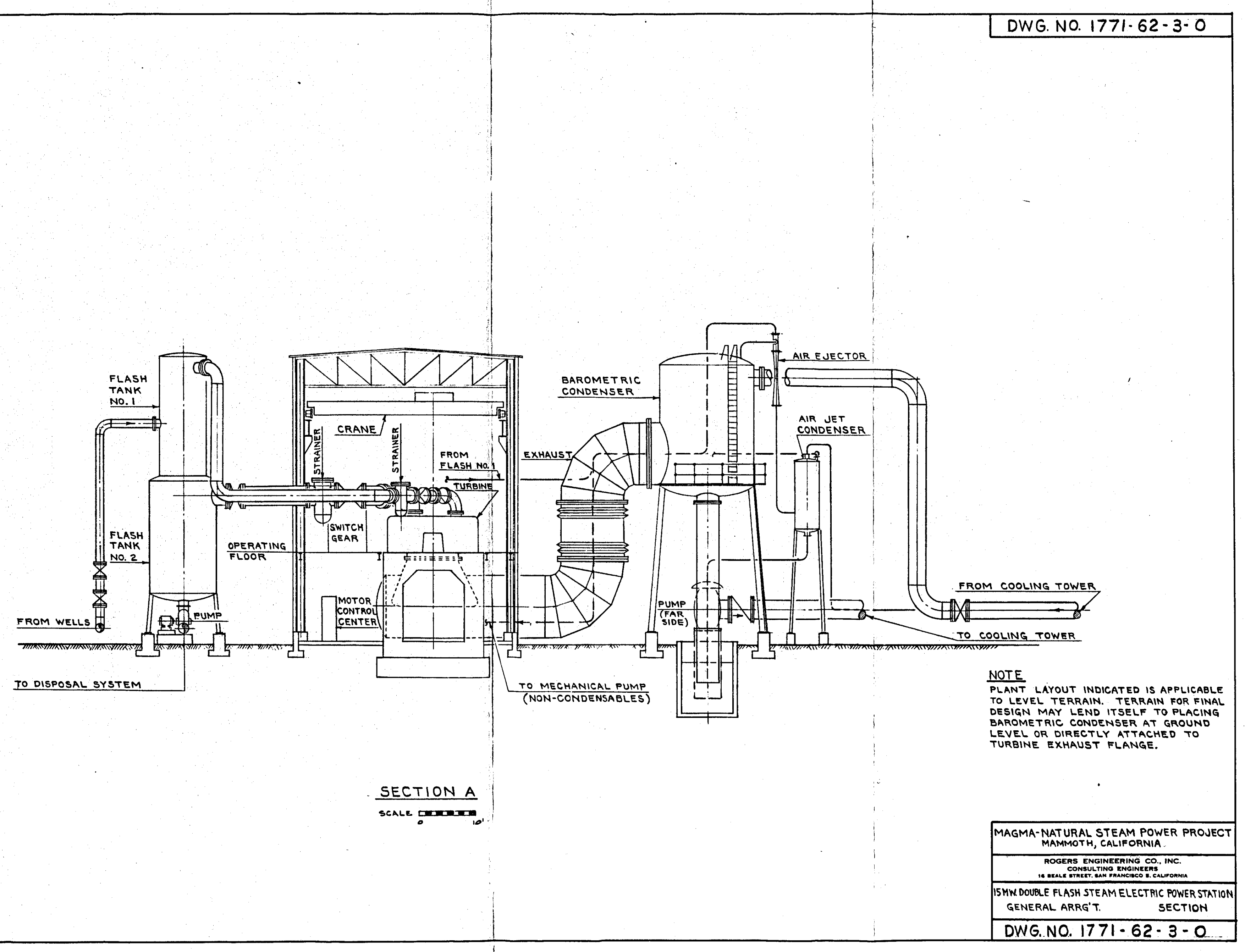




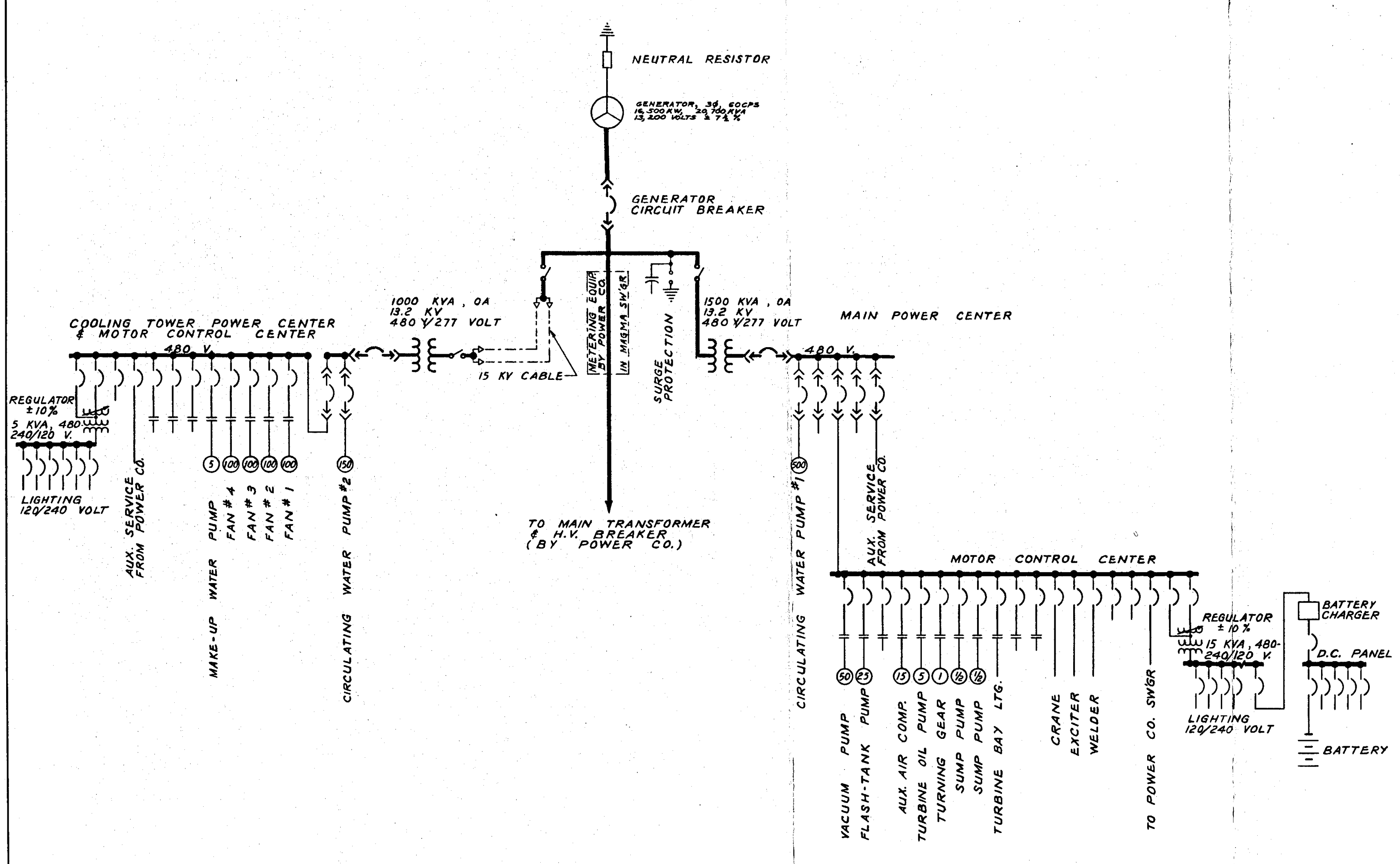




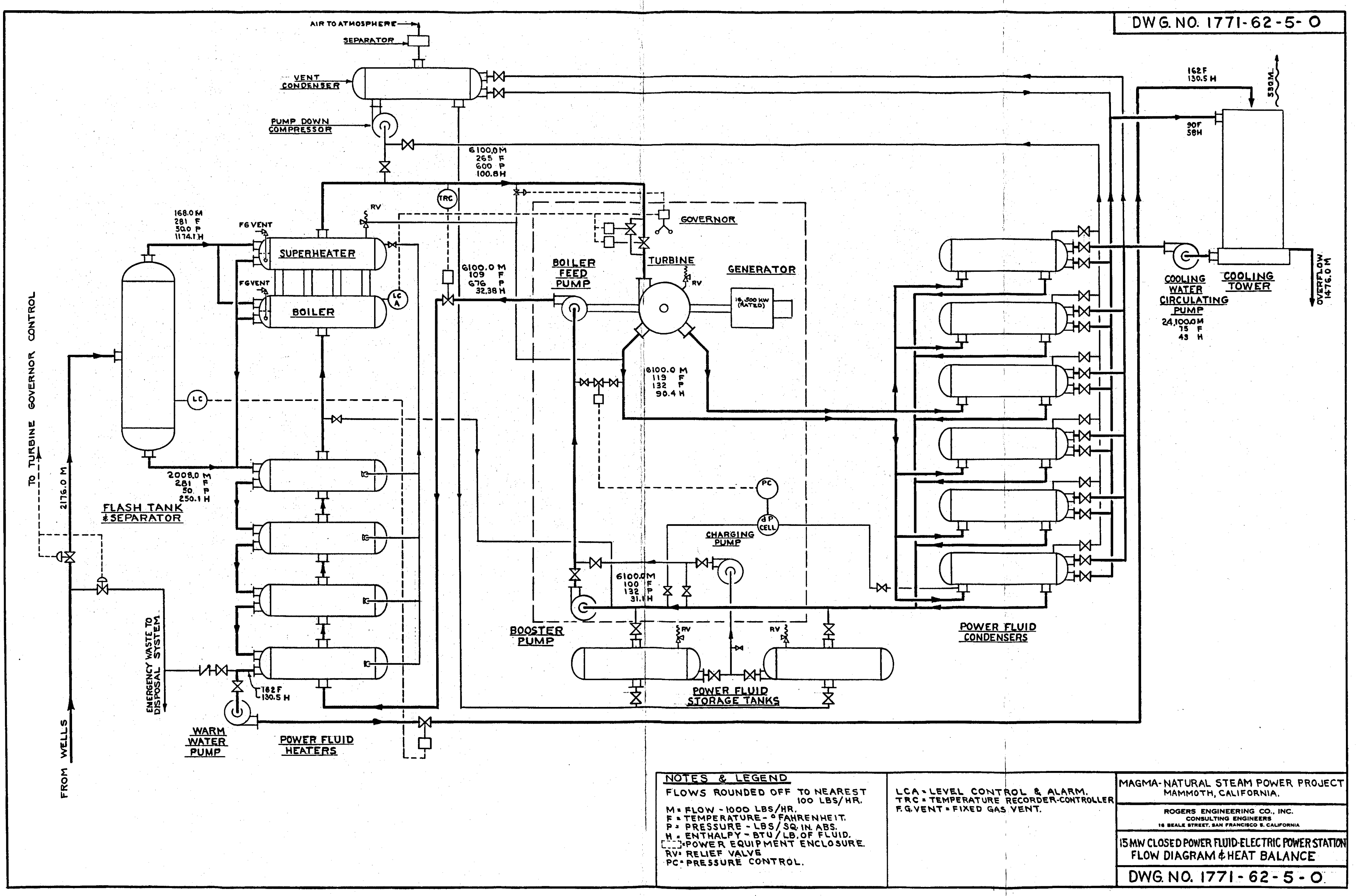




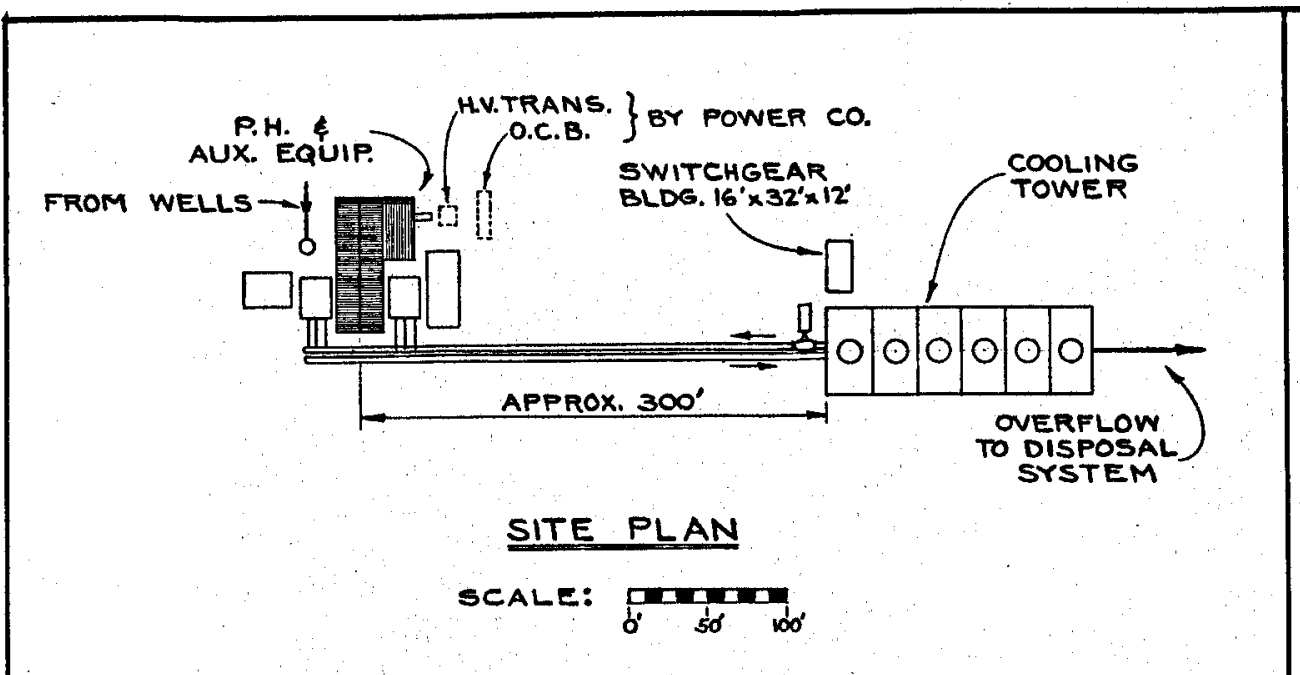

SWITCHGEAR.

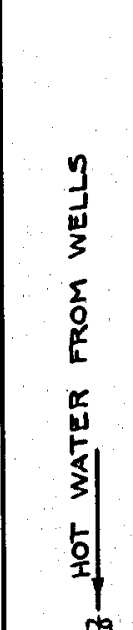

$x$

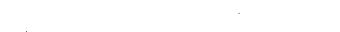

SCALE: Dion
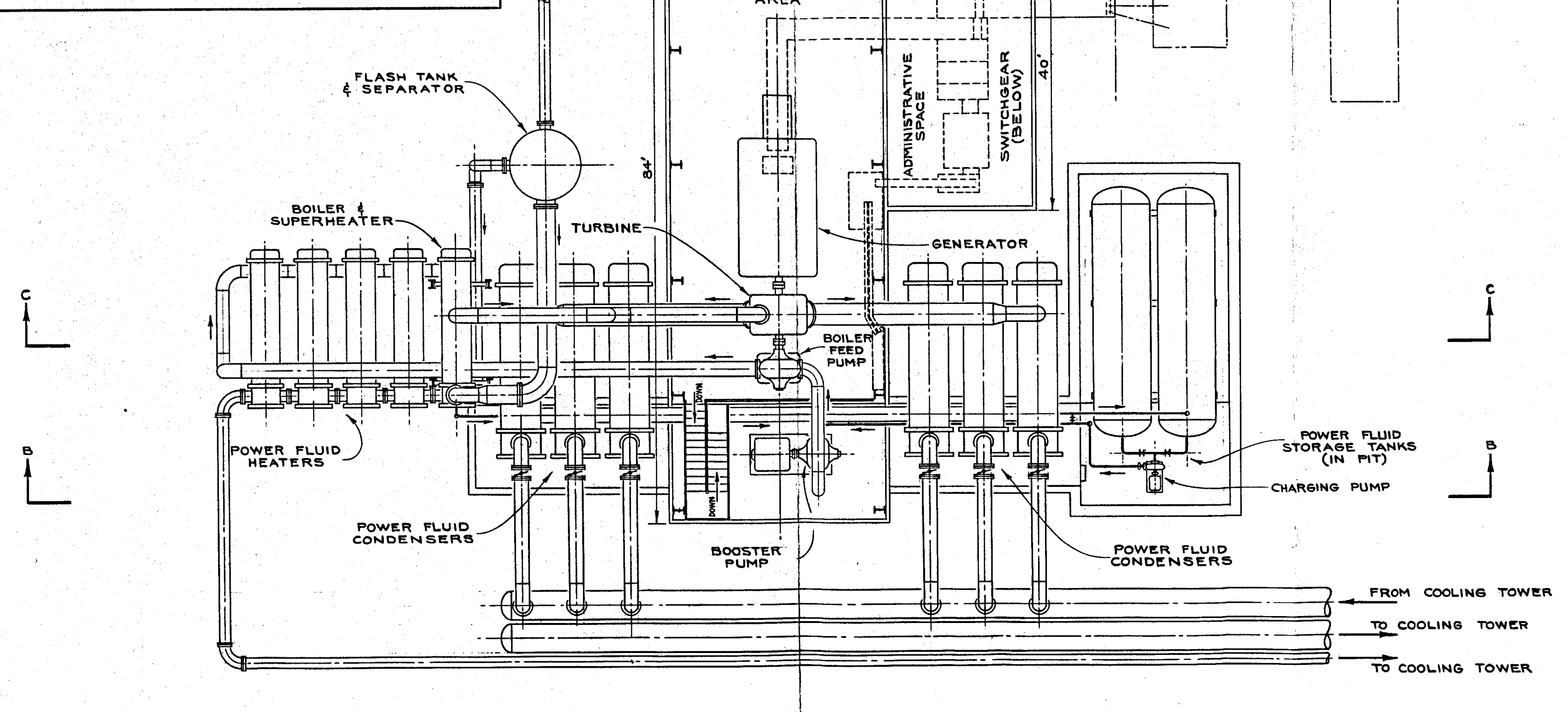

POWERHOUSE PLAN

MAGMA-NATURAL STEAM POWER PROJECT
MAMMOTH, CALIFORNIA.

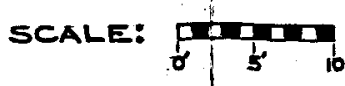




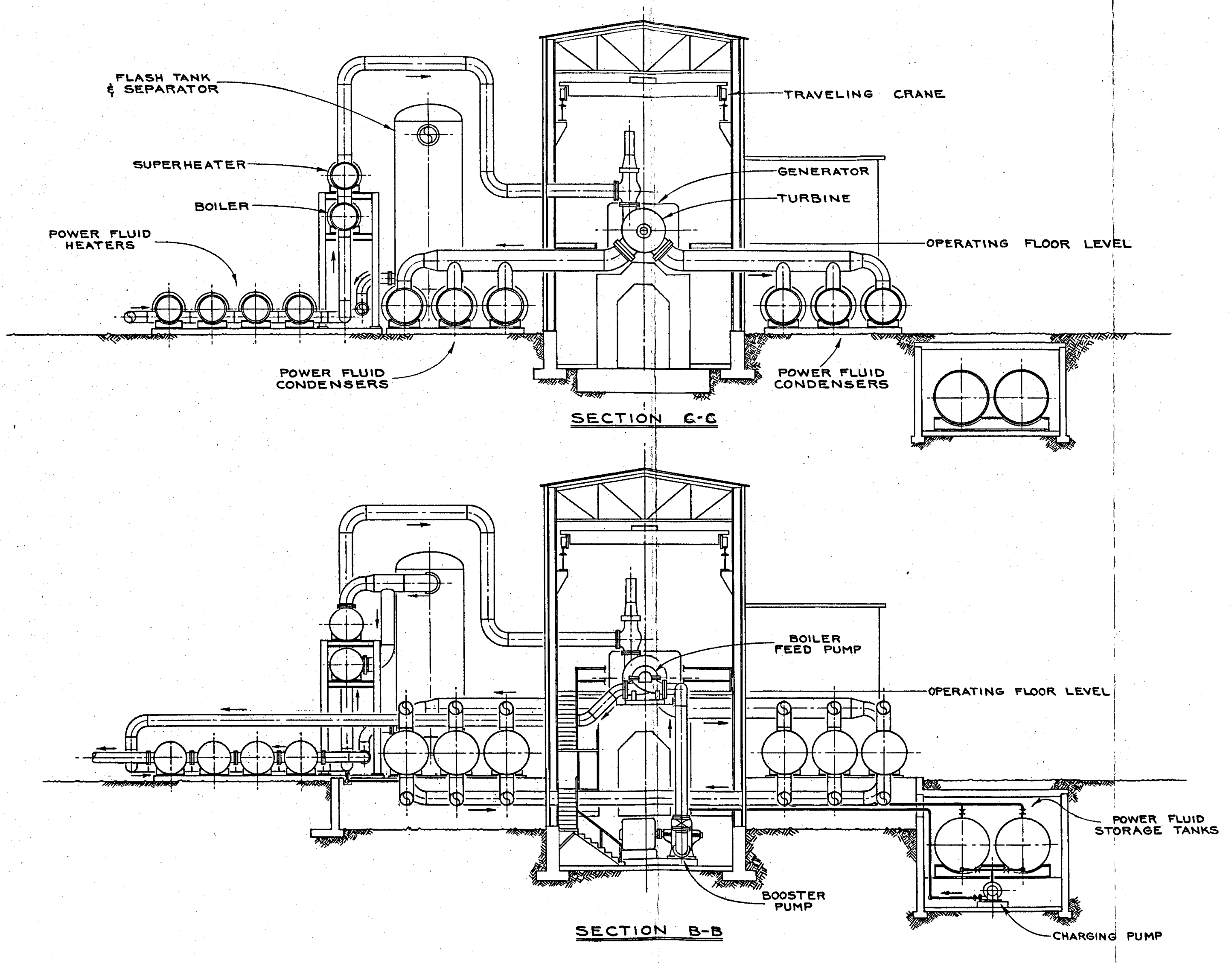

MAGMA-NATURAL STEAM POWER PROJECT

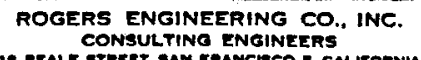

MW GOSED POWER FUID EECTRIC POWER STA GENERAL ARRG'T. SECTIIONS DWG.NO. 1771-62-7-O 


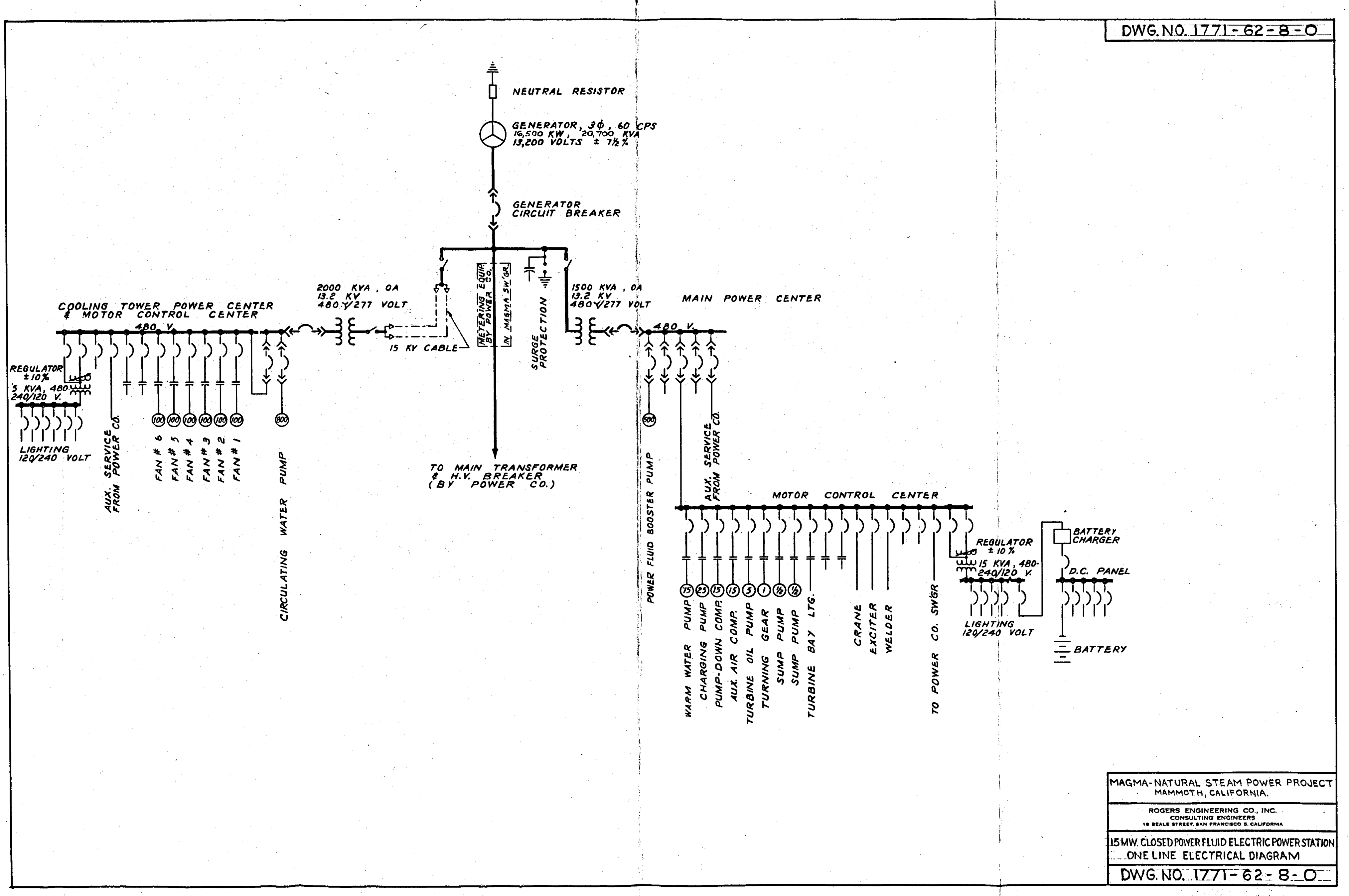




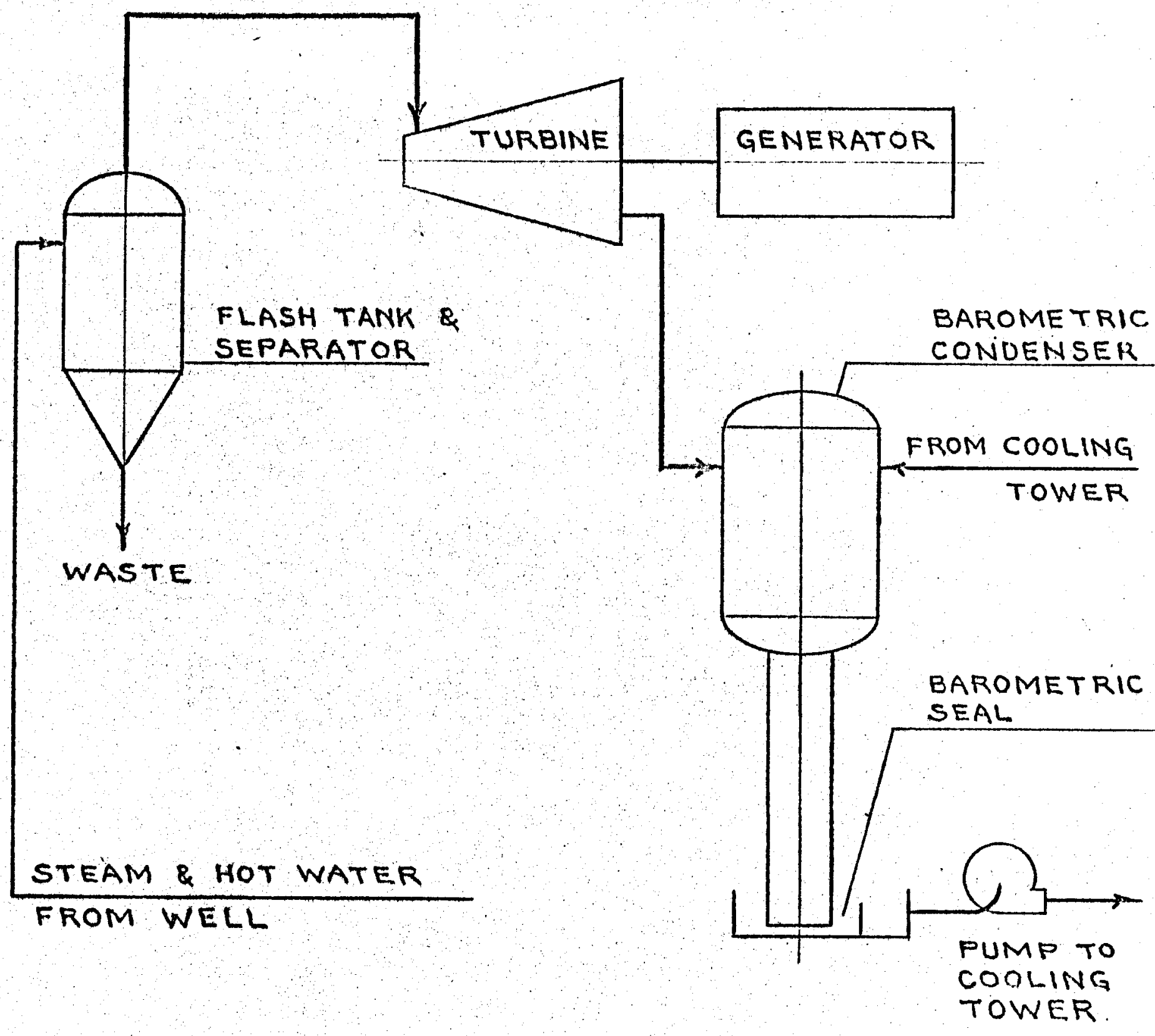

SINGLE FLASH HEAT CYCLE ROGERS ENGINEERIŃG CO., INC. CONSULTING ENGINEERS IO BEALE STREET. SAN FRANCISCO 5. CALIFORNIA

$$
\text { JOB } 1771
$$




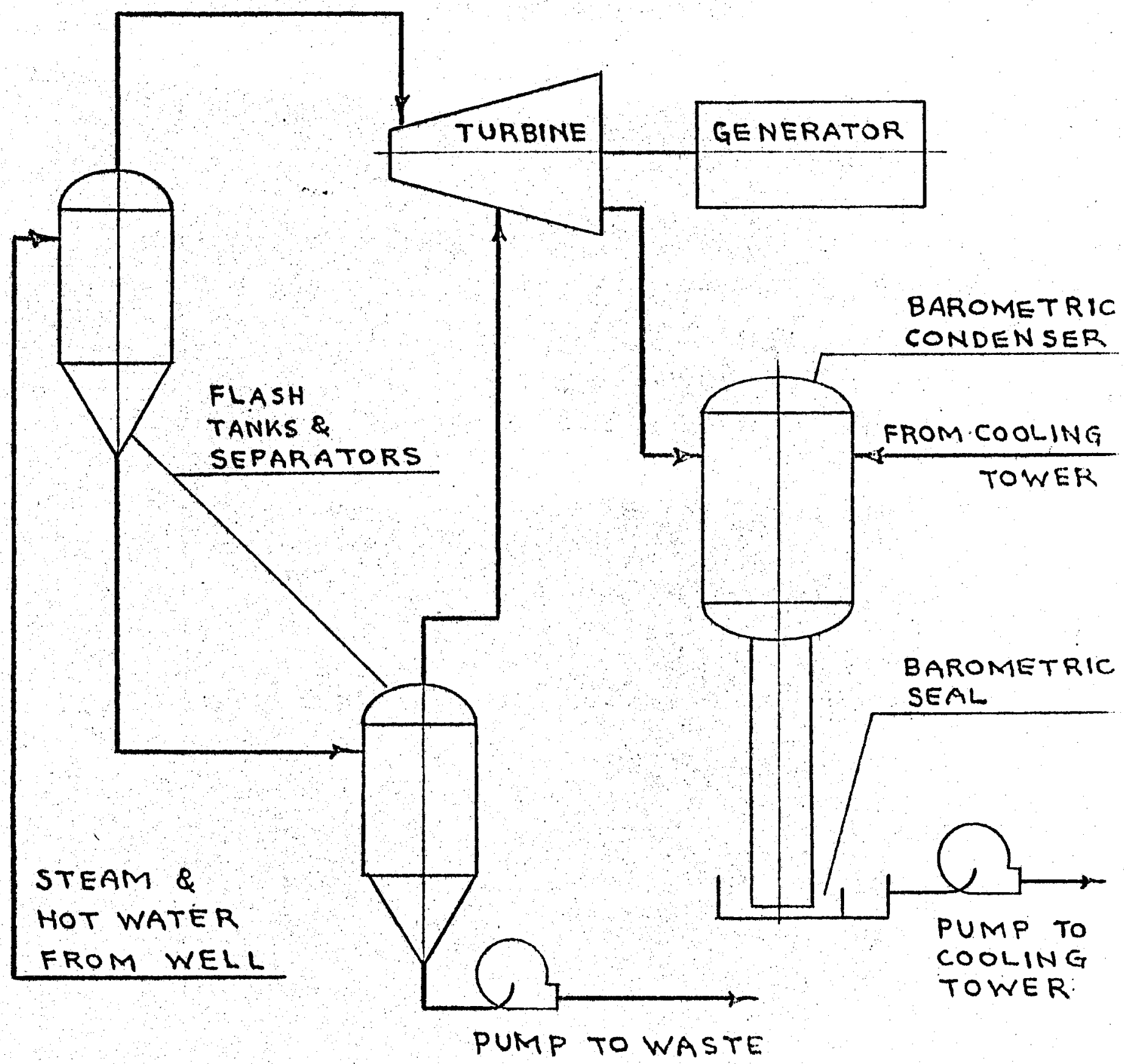

DOUBLE FLASH HEAT CYCLE

ROGERS ENGINEERING CO., INC. CONSULTING ENGINEERS

16 BEALE STREET, SAN FRANCISCO 5. CALIFORNIA

JoB 1771 


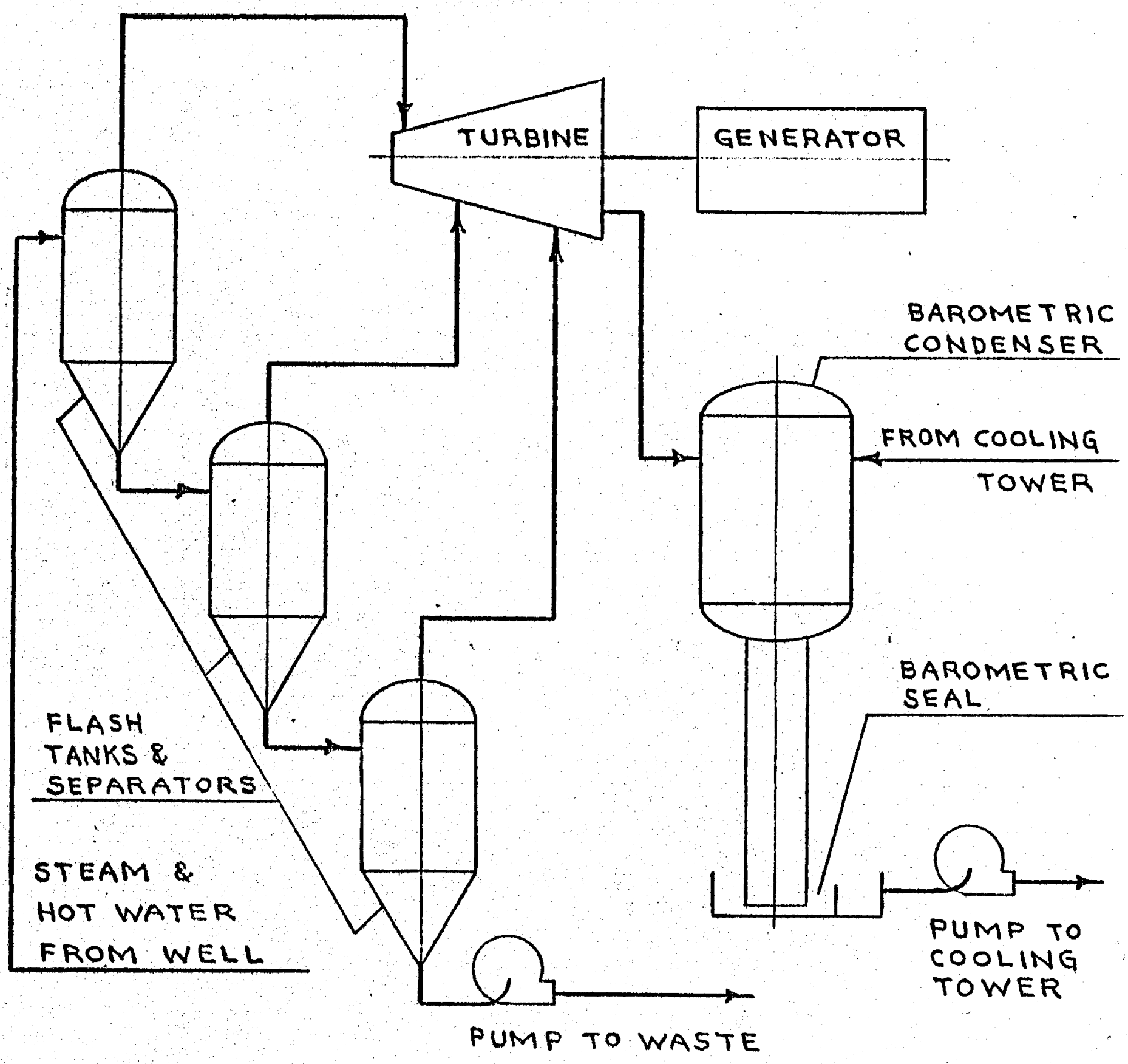

TRIPLE FLASH HEAT CYCLE

ROGERS ENGINEERING CO., INC. CONSULTING ENGINEERS

16 BEALE STREET, SAN FRANCISCO 5. CALIFORNIA

JoB 1771 


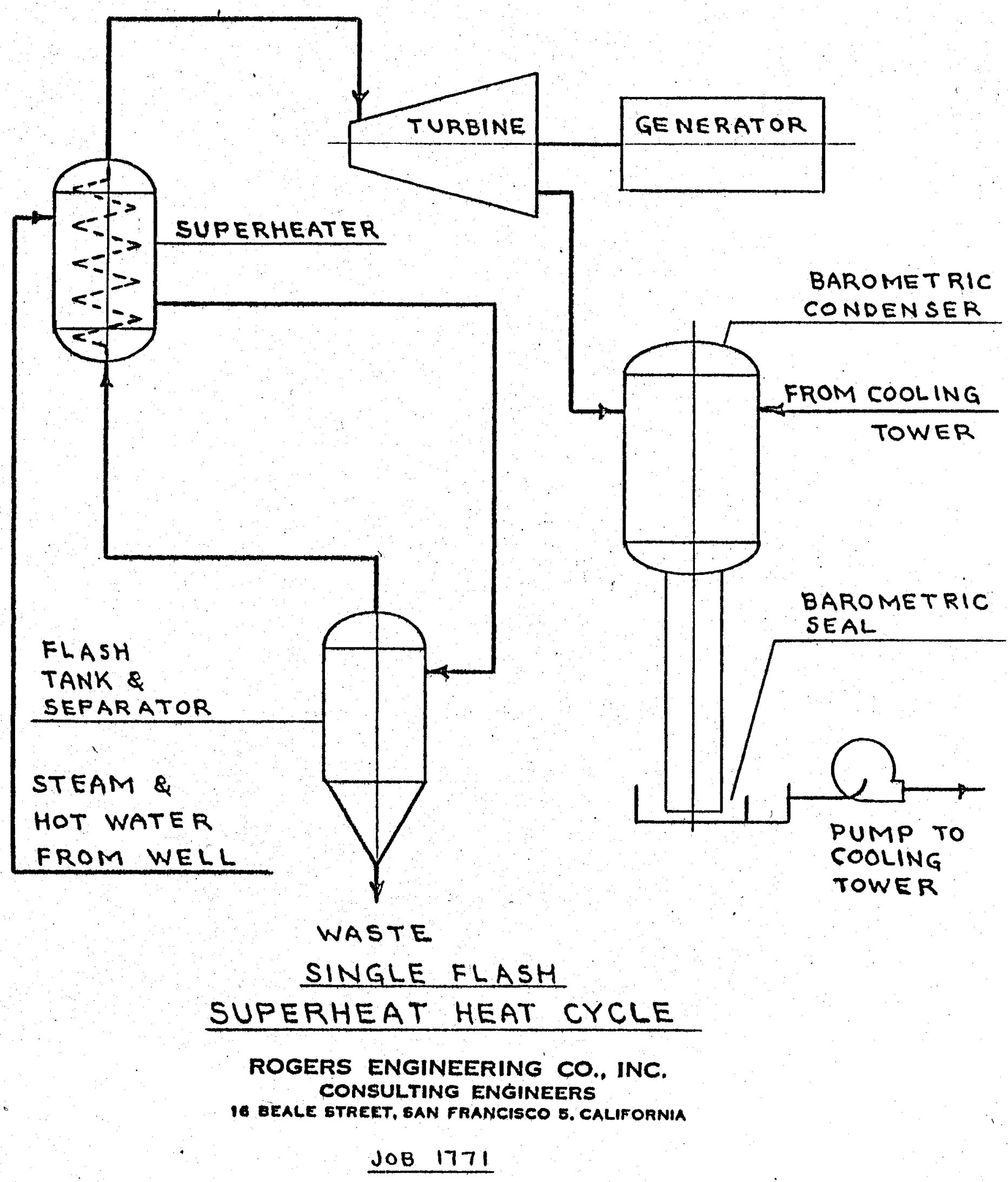




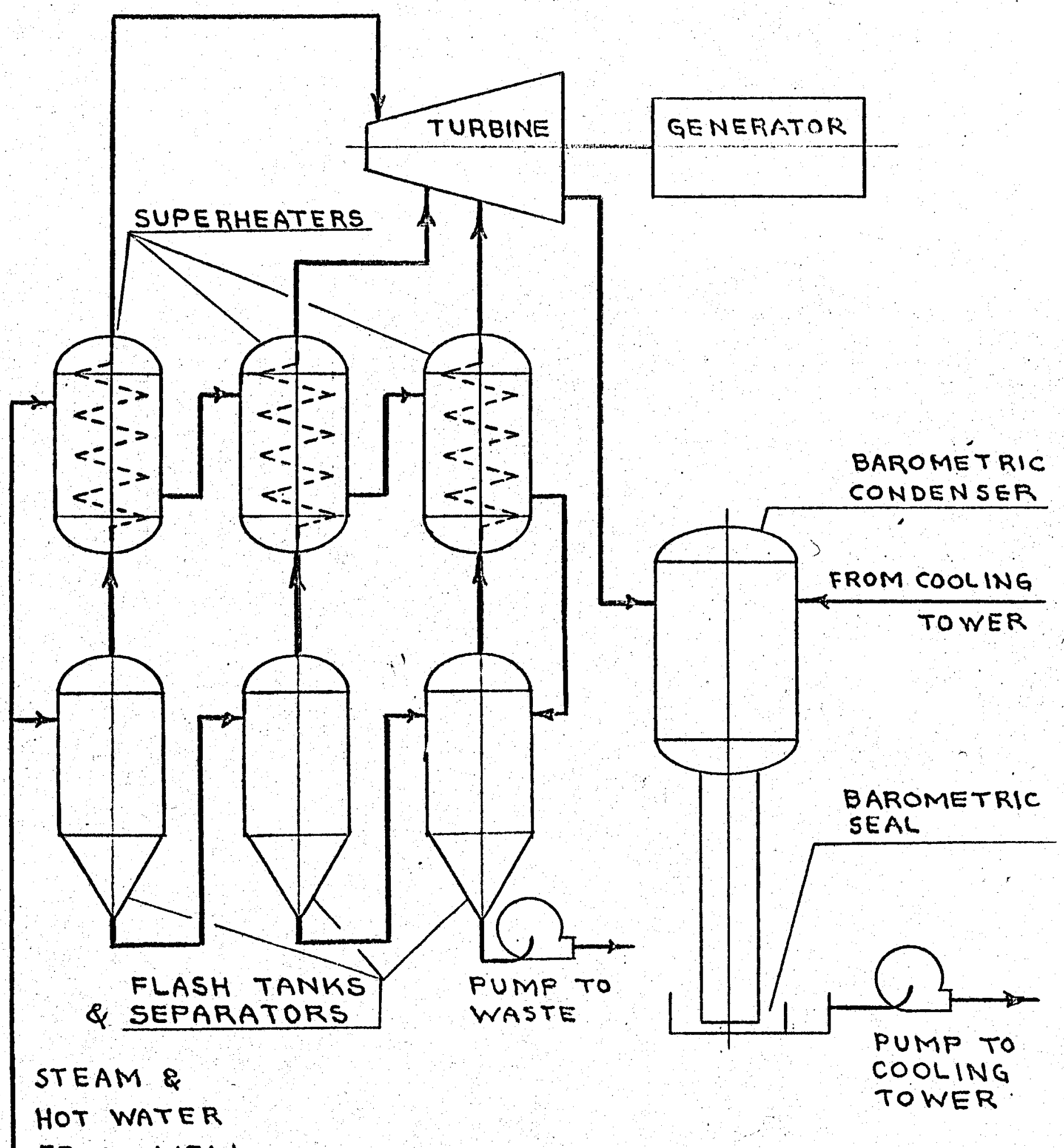

FROM WELL

TRIPLE FLASH

SUPERHEAT HEAT CYCLE

ROGERS ENGINEERING CO., INC.

CONSULTING ENGINEERS

16 geale gtReEt, ban francisco 5. California

JOB 1771 


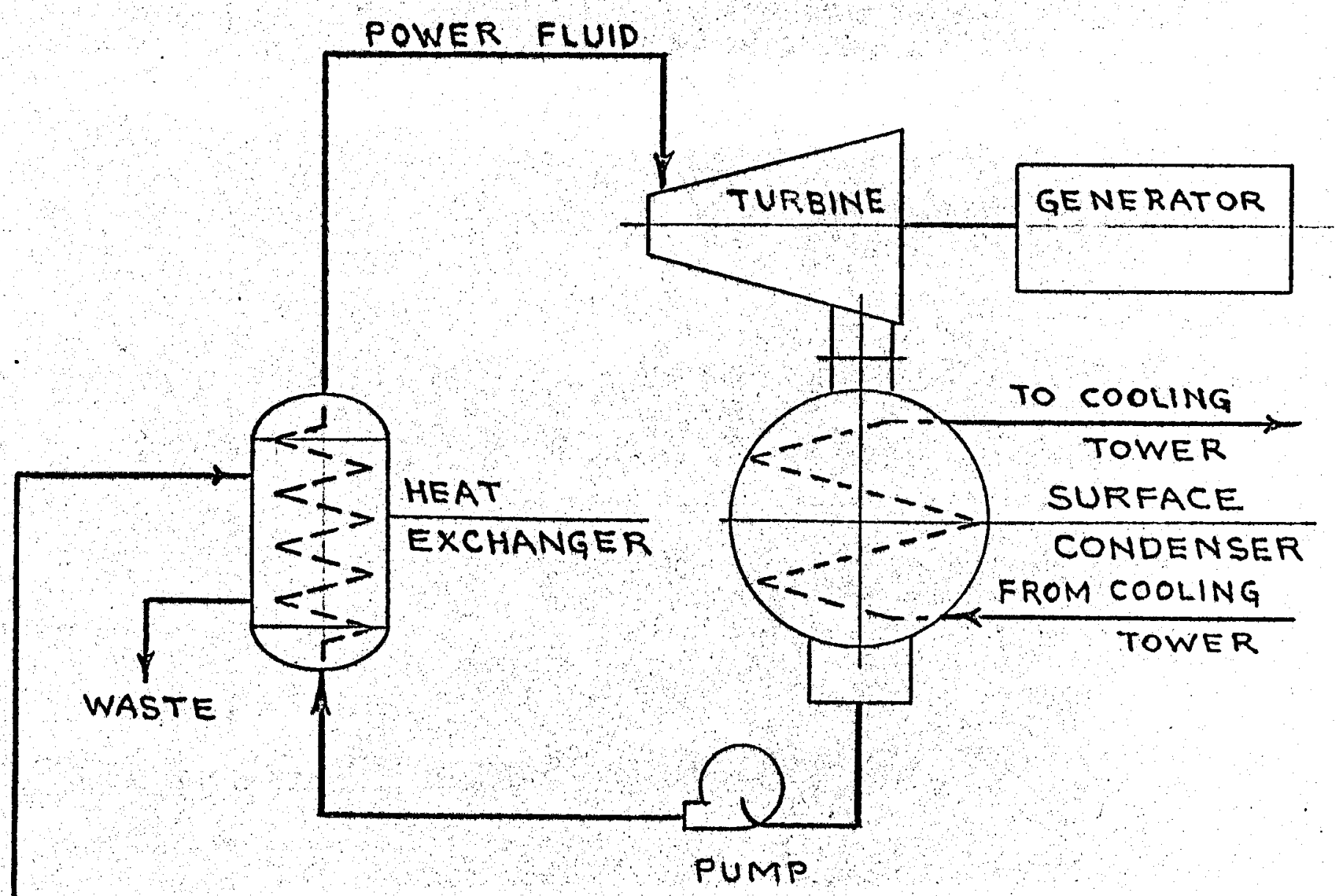

STEAM \&

HOT WATER

FROM WELL

CLOSED POWER FLUID HEAT CYCLE

ROGERS ENGINEERING CO., INC. CONSULTING ENGINEERS

I6 GEALE STREET, SAN FRANCISCO 5. CALIFORNIA

JOB 1771 